\title{
Structural Health Monitoring of Old Industrial Structures
}

\author{
Piyush K. Bhandari, \\ Dept. of Civil Engg., \\ D. V. V. P. College of Engineering, \\ Ahmednagar, M.S., India
}

\begin{abstract}
Recent 2015 earthquake that had strike Katmandu region in Nepal have clearly indicated the negligence of the Government, engineers and the dwellers in following the Building code during its construction and use. If those buildings were evaluated structurally as per the norms, the picture would not have been so devastating. The structural engineers should have assessed the health and condition of old buildings. But the main problem here was lack of documents for conducting the survey. The whole survey was done in favor of client. It's a need to create awareness and impose the building byelaws so that it will be followed strictly, at least when it comes to the part of human life. Loss of human life is a great loss to nation which cannot be recovered in terms of any compensation.
\end{abstract}

Keywords-Earthquakes; building Code; health monitoring; old buildings; structures; industrial building

\section{INTRODUCTION}

The structure is assembly of load carrying members and must carry load throughout its design life. Since construction, structure must perform desired function of accommodation and service efficiently till end of its design life [1]. During the course of work it may get deteriorated and decrease its capacity. Hence it needs to be assessed time to time to know about its present status and how long it will withstand with present condition [2]. Also it is necessary to study the possible modes of corrective/ repairable measures to be undertaken to maintain its design life. In certain situation old buildings can be restored to even increase its design life. But its need careful and through investigation which is known as structural health monitoring of building. It is generally undertaken by experienced structural engineer. It may be assisted by the civil engineer or the local contractor who has actually undertaken that particular work since they better knows the alterations or corrections made while the structure was executed from paper to ground

\section{LITERATURE REVIEW}

Monitoring of steel structures requires a fair judgment and experience. In past investigation, power fingerprint analysis, neural network methods, genetic algorithm and wavelet analysis were used to identify the steel structural damages. It is required to access the structure in event of disaster to check the safety and integrity of structure [3]. In case of steel bridges, which are designed for life span of 50100 years, shows signs of distress and deterioration due to environmental and moving loads. They fail to perform as per designed. It becomes important to investigate the bridges within time before any failure or accident. With use of modern aid sensors, any sign of distress in steel bridges can be detected early and proper maintenance can be performed to protect from further damage [4]. Similarly in China, sensor technology was adopted consisting of piezoelectric material sensor with optic fibers connected to data monitoring and processing system. The system keeps a check on external loads, environmental effects on structure and assesses their effect on soundness of structure. Reliability of monitoring unit is important in structural health monitoring of concrete structures [5]. Structural health monitoring can be considered as automated technology monitoring structure continuously using less men power [6]. It is important to locate the critical points for fixing the sensors to get exact information. In case of steel structures, to measure extent of corrosion contact sensors were used because corrosion reduces the strength of steel members [7].

\section{CURRENT SCENARIO}

In present situation government efforts are found to be less to implement the building byelaws. As per law it is mandatory to undertake the condition assessment of building after completion of 15 years at regular stipulated intervals. But the Municipal Administration as well as engineers is not so serious about following this law. This law is violated in all metropolis including Mumbai, Pune, Nashik etc. Only in case of government buildings and to some extent registered societies are making the structural assessment of building. The individual citizen or society who is the client, hires the Structural engineer from the government nominated Panel. The Registered Structural engineering firms are offering the service of conducting structural assessment of building.

Structural health assessment of existing buildings is generally consisting of two categories:

1. Assessment of the overall integrity of buildings externally as well as internally

2. Assessment of buildings or its part that has been affected structurally by events, such as fires, vehicle impact, or flooding.

\section{STRUCTURAL ASSESSMENT IMPORTANCE}

The assessment has to be carried out by experienced person or firm since it has to deal with following conditions

a) The firm has to study, evaluate and submit report to client.

b) They have to ensure the dwelling in such structure thereafter is safe and feasible.

Follow all engineering principles while conducting the survey

Consequently, the responsibly of structural engineering in the assessments of old buildings strikes out to be quite 
important. And client is actually giving his faith and life in hands of structural consulting firm

\section{ASSESSMENT PROCEDURE}

The assessment has to be carried out by experienced person or firm since Client is supposed to make an agreement with the structural engineering firm to hand authority for conducting the work. The rights are required to be provided to the structural engineer for smooth and uninterrupted work:

a) Making available original design and construction drawings. If they are not available then giving permission for conducting filed survey and taking measurements of structural elements to calculate its load carrying capacity

b) Provide reports of previous assessment survey as well as maintenance work

c) Helping the engineer in locating the critical or susceptible areas

\section{A. Original Drawings and approvals:}

Engineers must have free access to original design and drawings prior to inspection. It will help to get the idea about exact situation of building. It will help to find critical areas of inspection. Define the loads and overloading situations if any. The drawings can denote any unauthorized addition or alternation work that may affect the RCC frame. In case of damage assessment of particular area of building, only the affected area is studied from the drawings and is further checked for its durability.

\section{B. Inspection:}

Structural engineering firm must notify the client exact procedure of inspection. One person from client side can accompany the engineers during inspection. The entire procedure includes:

a) Overall visual inspection to find out condition of building, indentify the structural defects, distress or deformation and material deterioration.

b) Calculate loading on members, check with the drawings and find out overloading locations

c) Any alternation or addition in building that may affect structural system

d) Find out the level of distress in building, suggest the immediate necessary action required to be taken for maintaining the life of structure

e) Take necessary decision for further detailed survey using NDT methods if any.

Visual inspection gives only brief idea of amount of structural distress. At many situations the engineers must not hesitate to ask the client for undergoing detailed investigation of the structures. It's the matter of concern with human life and any negligence in conducting assessment may prove fatal some other day.

\section{Analysis:}

Structural analysis becomes essential in case there is sign of structural distress and its causes are not evident. Also the structure has been subjected to recent change in its structural loading which was not accounted during its design. Entire analysis is based on original documents and drawings or on the measurements of existing members. The analysis has to be worked out based upon latest IS codes. Sometimes it becomes necessary to know the exact type and quality of material used during construction. The expert guidance becomes necessary in such situation. The expert engineer can analyze the present status of structural members by studying the deterioration of surface concrete, corrosion in steel members, cracks and bends in wooden members etc. Its opinion can be the game changer in case of repairs and rebuilding work. The present condition of building should not be related with its previous best performance as per design codes used during its design and construction, they are lacking in lots of revision and addition made today. The building has to be assessed as per present existing codes and byelaws.

Also in many cases only part of a structure has been subjected to failure or damage, so only that part needs to be assessed instead of entire structure. Since the entire Auditing process is quite expensive though it's a matter of one's life and safety. At such situation the structure integrity cannot be compromised.

\section{Report:}

Lat stage of auditing work includes submitting the report as per the assessment made and the client's requirement. Report must include the method adopted for analysis, expert findings regarding present condition of structure. Report may be summarized in short or in detail as per auditing demand. If client wants the suggestions regarding repairing and retrofitting methods it may also be provided depending upon the expertise and knowledge of auditing firm.

The report includes:

1. Name and license number of Structural auditing firm/ engineer.

2. Reason for performing the audit

3. Name and address of client

4. Description of building including its architectural and structural drawings

5. Previous audit report and repair worked carried out if any.

6. Analysis findings:
a. Method of analysis
b. Expertise involved in auditing process
c. Observations regarding present condition
d. Signs of structural distress and deformation in members and their extent of damage
e. Expert opinion whether structure is fit for use or not
f. Repair methods suggested (optional as per client requirement)
g. Limitations on Auditor's work
h. Recommended extra investigation by advanced methods like NDT.
i. Approximate cost of auditing work
j. Design codes and byelaws adopted during auditing work.




\section{CONCLUSION}

Till date it in not possible to exactly predict the service and useful life of a building. Though the facts behind this are not certain at least we have to develop a system to regularly assess the health of existing building in order to keep them fit and fine. As doctor examines and suggests medication to patients in the similar way the Structural auditor has to assess the present status of building, find out the areas of distress and suggest suitable repair method. For that Auditor needs to possess prevalent technical experience. Clients or the housing society on their part must play active role during entire auditing procedure as well as they must follow the instructions and recommendations of audit report. The entire process of auditing itself has been made compulsory by local municipal agency for the sake of dwellers safe and healthy life. And ignoring to this can prove fatal that has been seen in previous cases.

\section{ACKNOWLEDGMENT}

The author would like to acknowledge the Head of civil Engineering Department, Principal and management of Dr. Vithalrao Vikhe Patil College of Engineering, Ahmednagar for providing laboratory facility for performing the research investigation work.

\section{REFERENCES}

[1] K.P. Chong, "Health monitoring of civil structures", Journal of Intelligent Material Systems and Structures, 199, vol. 9 (11), pp. 892898.

[2] F.K. Chang, "Structural health monitoring: A summary report", 2nd International Workshop on Structural Health Monitoring Proceedings, Technomic Publishing Company, Lancaster, UK, 1997, pp. 3-11.

[3] X. Wang, W. B, "Structural Health Monitoring for Steel Structures", Applied Mechanics and Materials. 2013, pp. 351-352, https://doi.org/10.4028/www.scientific.net/AMM.351-352.1088

[4] M. Modares and N. Waksmanski, "Overview of Structural Health Monitoring for Steel Bridges", Practice Periodical on Structural Design and Construction, 2013, vol. 18, Issue. 3.

[5] Huia Land Jinping O, "Structural Health Monitoring: From Sensing Technology Stepping to Health Diagnosis", The Twelfth East AsiaPacific Conference on Structural Engineering and Construction, Procedia Engineering, 2011, vol. 14, pp. 753-760.

[6] M. Sun, W.L. Staszewski and R.N. Swamy, "Review Article: Smart Sensing Technologies for Structural Health Monitoring of Civil Engineering Structures", Advances in Civil Engineering, 2010.

[7] Y.J. Cha, Y. Kim, and T. You, "Editorial: Advanced Sensing and Structural Health Monitoring”, Journal of Sensors, 2018. 